contributions herald a PAGES initiative aimed at the high-resolution reconstruction of climate history obtained through lake records from South America, Africa, and China. Another contribution focuses on deep-sediment drilling efforts in old crater lakes. These initiatives use a number of the techniques described above, which allow for the study of global teleconnections of climate variability at timescales of $10^{5}$ to $10^{2}$ years, while also revealing distinct regional and/or sub-continental climate features. Such regional syntheses are crucial for establishing the spatial and temporal patterns of climate change across climatic, hydrological, and ecotonal boundaries, thereby separating climatedriven and anthropogenic impacts on ecosystems at both the site-specific and landscape scales.

Rioual and Wang (p. 110) provide a review of progress in Chinese paleolimnological studies, particularly highlighting records that trace the past dynamics of Asian monsoon systems and the Westerlies, which provide a better understanding of complex atmospheric teleconnections. Verschuren and Russell (p. 112) highlight the regionally different patterns of hydro- logical change during recent millennia, as reconstructed using novel temperature and moisture proxies in lakes across tropical Africa. They also demonstrate how paleogenetic tools can improve our understanding of climate-human-ecosystem interactions. García-Rodríguez et al. (p. 115) demonstrate the value of integrating data obtained through paleolimnological studies in Argentinean and Uruguayan Holocene lake records. They focus particularly on the links between past monsoonal activity and regional hydrological variability since late Glacial times in the Pampas. Finally, Pienitz et al. (p. 117) provide an update on progress in the recovery of long sediment records from continental sites and, in particular, large and deep crater lake basins. They highlight three projects funded through the International Continental Scientific Drilling Program and other partners.

The final contribution to this issue is a Program News by Gell et al. (p. 119). They report on the European Water Framework Directive and the important role paleolimnology can play in assessing ecological baseline conditions for lakes.

\section{Outlook}

The various contributions in this issue of PAGES news show that paleolimnology has reached a stage where high-precision data based on different proxies can be generated for lake records. Based on a vast amount of data gathered and standardized approaches, paleolimnologists are now in a position to document continentto hemispheric-wide sensitive responses of freshwater systems to ongoing global change.

\section{References}

Battarbee, R.W., et al., (Eds) 2004: Past Climate Variability through Europe and Africa, Developments in Paleoenvironmental Research Volume 6, Springer, Dordrecht: 638 pp.

Birks, H.J.B., 1998: Numerical tools in palaeolimnology - Progress, potentialities, and problems, Journal of Paleolimnology, 20: 307-332.

Lotter, A.F. and Birks, H.J.B., 2003: The Holocene palaeolimnology of Sägistalsee (1935 m asl) and its environmental history - a synthesis, Journal of Paleolimnology, 30: 333-342.

Pienitz, R., et al., 2004: Long-Term Environmental Change in Arctic and Antarctic Lakes, Developments in Paleoenvironmental Research Volume 8, Springer, Dordrecht: 562 pp.

Smol, J.P., 2008: Pollution of Lakes and Rivers: A Paleoenvironmental Perspective - 2nd Ed., Wiley-Blackwell Publishing, Oxford: 383 pp.

For full references please consult:

www.pages-igbp.org/products/newsletters/ref2009_3.html

\title{
The potential of high-resolution X-ray fluorescence core scanning: Applications in paleolimnology
}

\author{
Pierre Francus ${ }^{1}$, H. Lamb² ${ }^{2}$ T. Nakagawa ${ }^{3}$, M. Marshall ${ }^{2}$, E. Brown ${ }^{4}$ and Suigetsu 2006 Project Members $^{5}$ \\ ${ }^{1}$ Centre Eau, Terre et Environnement, INRS, Québec City, Canada; and GEOTOP, Montréal, Canada; pfrancus@ete.inrs.ca \\ ${ }^{2}$ Institute of Geography and Earth Sciences, Aberystwyth University, UK; ${ }^{3}$ School of Geography, Politics and Sociology, University of Newcastle, \\ UK; ${ }^{4}$ Large Lakes Observatory and Department of Geological Sciences, University of Minnesota Duluth, USA; ${ }^{5}$ www. suigetsu.org/
}

\section{A new generation of XRF core scanners allows rapid, non-destructive acquisition of high-resolution geochemical and X-radiographic data from lacustrine sediment cores, facilitating new approaches to many applications in paleolimnology, including pollution detection, varve counting, and estimation of past ecosystem productivity.}

X-ray fluorescence (XRF) core scanning was developed in the late 1990s (Jansen et al., 1998) and is a powerful analytical technique: it is fast, requires no sample preparation, and it can detect most chemical elements of the periodic table down to limits of a few ppm, depending on acquisition dwell time and sample conditions. A new generation of XRF core scanners allowing high resolution analysis, with improved count rates and detection limits, has become widely available. One of these, the Itrax ${ }^{\mathrm{TM}}$ core scanner, takes high resolution radiographic and optical images at the same time as XRF measurements. It has a flat $X$-ray beam with a measurement area of $100 \mu \mathrm{m} \times 4 \mathrm{~mm}$ (or 200 $\mu \mathrm{m} \times 8 \mathrm{~mm}$ ), rather than a spot beam, so that grain-to-grain variance is averaged in the horizontal core axis, ensuring predominance of the environmental signal through depth (Croudace et al., 2006).

\section{Practicalities}

High-resolution non-destructive analyses of lacustrine sediments can be achieved with an XRF core scanner in a remarkably short time. For example, a $1.5 \mathrm{~m}$-long core section can be scanned at $1 \mathrm{~mm}$ intervals in about 13 hours, with a dwell time of 30 seconds. Using a Mo X-ray tube, light elements such as $\mathrm{Al}$ and Si require long dwell time (>20 sec.), while heavier elements, such as $\mathrm{Fe}, \mathrm{Ca}$, $\mathrm{Ti}$, are more easily detected with reduced dwell times. Numerous factors related to the sediment matrix, such as water content, organic matter, grain size, mineral crystallinity and porosity may have a significant impact on the production and the detection of fluorescent photons (Weltje and Tjallingii, 2008). Results are usually presented as spectral peak areas or counts per second (cps) and can be calibrated to concentration, although this may be cumbersome in some sediments because of the high variability of the matrix factors mentioned above. The use of element ratios and the plotting of XRF curves (in cps) together with discrete sample analyses obtained using destructive techniques, such as inductively-coupled plasma or other conventional techniques (Fig. 3a), are two ways to evade this issue. The Itrax ${ }^{\mathrm{TM}}$ core scanner also provides high-resolution $\mathrm{X}$-radiographs that are useful for detecting invisible sedimentary structures.

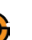




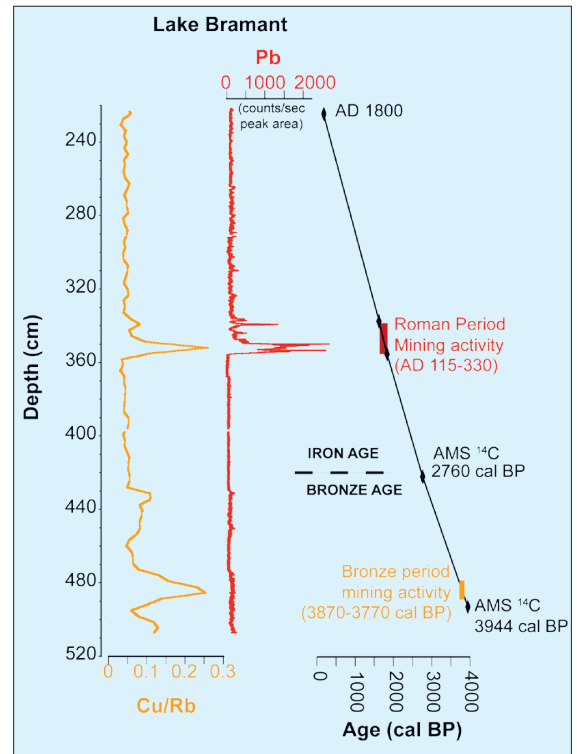

Figure 1: Lake Bramant, French Alps. Copper and lead profiles reveal metallic pollution during the Bronze and Roman periods. Age model based on radiocarbon dates (modified from Guyard et al., 2007).

\section{Applications}

XRF core scanners offer many potential applications in paleolimnology. For routine core logging, they complement other non-destructive techniques such as CTscan and Multi-Sensor Core Logging systems (St-Onge et al., 2007). Direct applications include the detection of tephra layers and metal pollution signatures. They can also be used for provenance studies, for the reconstruction of past lake conductiv- ity from element ratios in carbonate sediments, for estimating past weathering, leaching and erosion intensities, primary productivity, and paleo-redox conditions, as well as for sub-millimetre scale analysis and counting of fine laminations. Here, we highlight three examples of applications.

\section{Pollution signatures}

Sediment cores from high-elevation alpine Lake Bramant (western Alps, France) were logged using several techniques, including XRF scanning (Guyard et al., 2007). The analyses showed two marked increases in lead and copper concentrations (Fig. 1). The age model dated these events to around $3.8 \mathrm{ka} \mathrm{BP}$ and to AD 115-330. The former is reflecting local atmospheric pollution due to mining activity during the early Bronze Age, as confirmed by archeological evidence. The younger peak in heavy metal concentrations corresponds to the height of Roman industrial activity in the area, as recorded in historical and archeological archives. These results are supported by evidence of lead contamination at several locations in the region and from various other paleo-archives, including ice cores from Greenland (Rosman et al., 1997). Although it was not the primary goal of the study to find traces of contamination, systematic high-resolution XRF scanning revealed this important result.

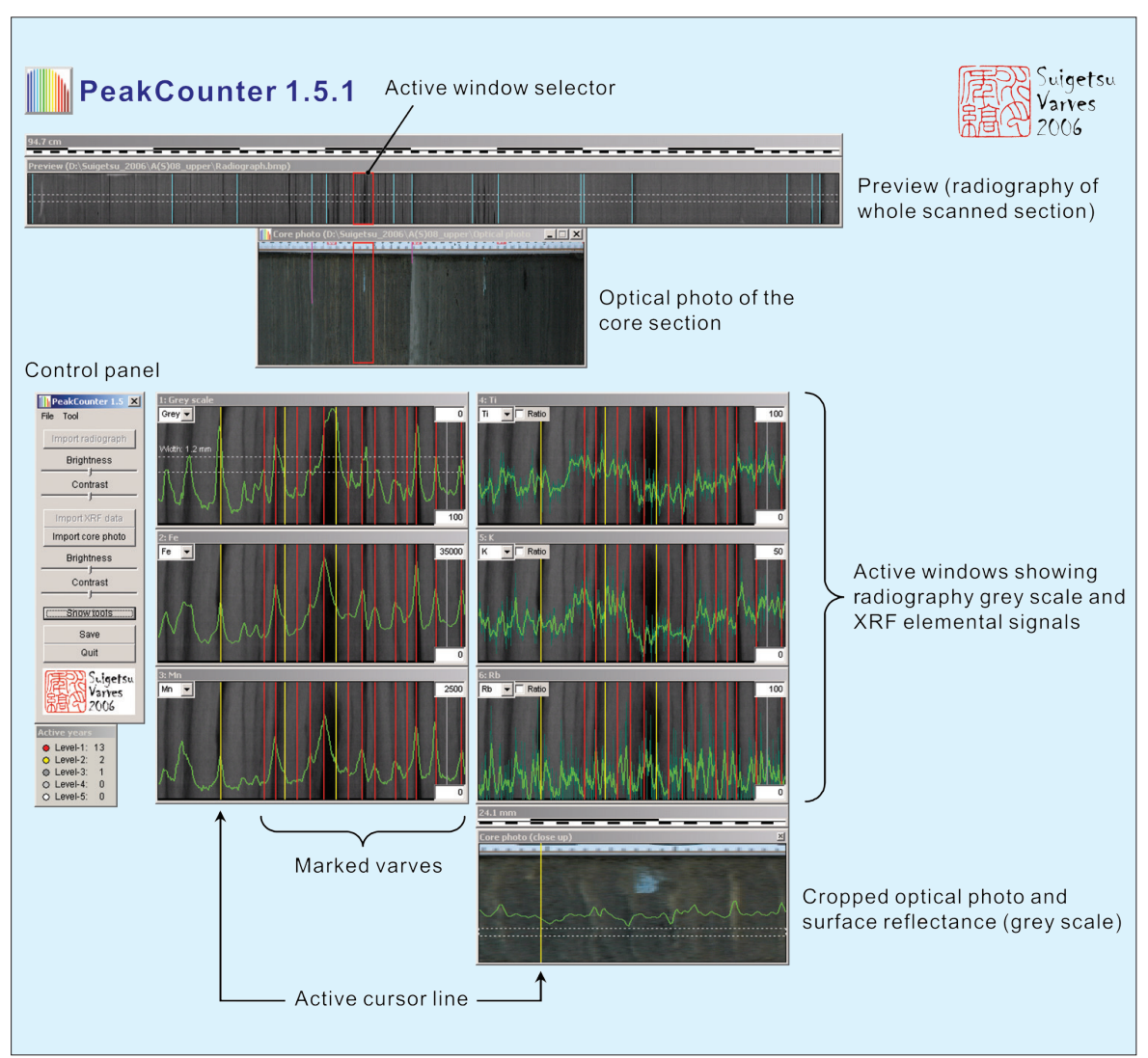

Figure 2: Screenshot views of PolyCounter 1.5, a newly developed user-friendly software for varve counting using Itrax output data files. Green lines show XRF measurements or radiograph gray scale value (measured automatically on the image file); yellow lines indicate active cursor lines; red lines mark varve boundaries; light blue and pink lines indicate event layers, which are useful for aligning radiograph and optical photo. The installer package is available at http://dendro.naruto-u.ac.jp/ nakagawa/.

\section{Varve counting}

In 2006, a new continuous 73.5 m-long sediment core was retrieved from Lake Suigetsu, Japan. The core (SG06) is rich in terrestrial plant macrofossils, providing a unique 60-ka history of atmospheric radiocarbon in an annually laminated record. The Suigetsu Varves 2006 Project will contribute to the international terrestrial radiocarbon calibration model, extending it to $>50 \mathrm{ka}$. Thin-section microscopy, and high-resolution Itrax XRF and $\mathrm{X}$-radiography were the two independent methods used for varve counting. Comparisons between counts from XRF-scanning and thin sections allowed internal errors to be quantified and dramatically reduced. Double-L channel core sections (Nakagawa, 2007) were scanned at $60 \mu \mathrm{m}$ intervals, and the data analyzed with PeakCounter (http://dendro.narutou.ac.jp/ nakagawa/). This software was specifically developed for varve counting using multi-parameter data from the Itrax scanner. An active window selector plots up to six different parameters (e.g., radiography grey scale, selected XRF elements, or ratio between them), in separate windows using the equivalent radiograph area as the background image (Fig. 2). The active area of the optical image is also shown in a separate window, from which a grayscale plot can be derived as supporting information. A cursor line moves simultaneously in all active windows, allowing the user to mark the exact varve positions. Correlated peaks in the parameter and grayscale plots are marked with the numbers 1 to 5 , denoting the counter's judgment that they represent true varves. After cross-checking against parallel thin section counts, marks at different confidence levels are counted as 1, $0.5 \pm$ 0.5 , or 0 years, following the Greenland ice core layer-counting protocols (Rasmussen et al., 2006). Most of Lake Suigetsu's varves contain an end member rich in siderite, clearly evident as peaks in Fe and $\mathrm{Mn}$ (the latter being incorporated into the $\mathrm{FeCO}_{3}$ lattice) that coincide with optically distinct layers of high sediment density. The XRF data also allow detrital clay and tephra layers to be identified and removed from the ultimate age-depth model based on varves.

\section{Biogenic silica}

Biogenic silica (BSi) distributions in lake sediments record variability in the productivity of diatoms and other siliceous algae, and may be used to evaluate past climate conditions in continental settings (e.g., Colman et al., 1995). Classic determination of BSi in sediments involves la- 

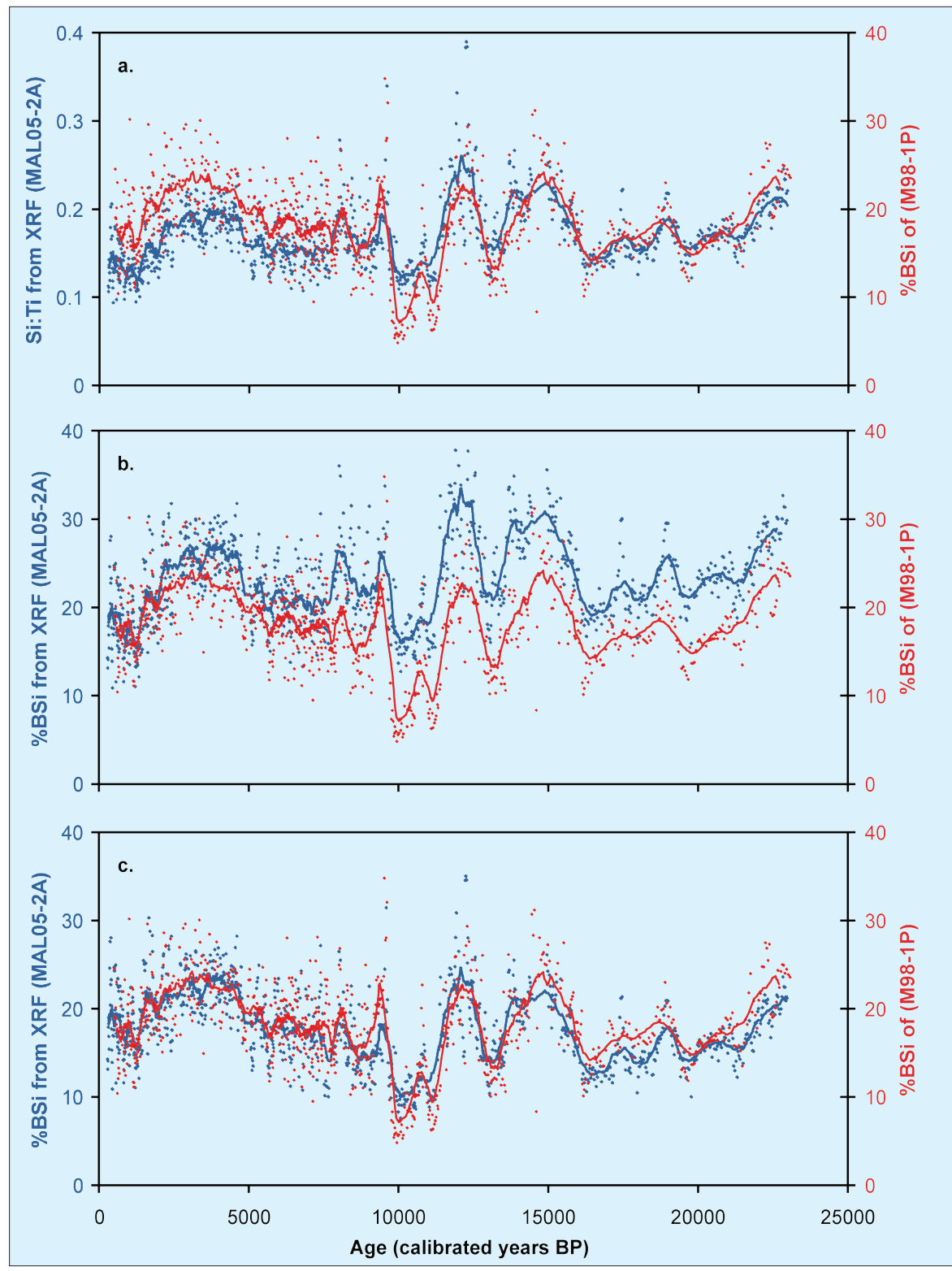

Figure 3: Application of XRF corescanning to infer \%BSi in Lake Malawi sediments. a) Comparison of uncalibrated Si:Ti $i_{\text {XPF }}$ (blue) with measured \%BSi (red). XRF measurements were made at 1 - $\mathrm{cm}$ resolution in the uppermost $9 \mathrm{~m}$ of drill core MAL 05-2A (Brown et al., 2007). \%BSi was determined with 1-cm resolution for a 9-m piston core (M981P) taken earlier at a nearby location (Johnson et al., 2002). Records have been tuned to a common chronology. Heavy lines represent 21-point running means. \%BSi determinations required nearly six months of laboratory work, while the XRF analyses were completed in less than two days. b) Comparison of measured \%BSi with \%BSi estimated from Si:Ti $\mathrm{XPF}_{\text {us }}$ using fitting parameters empirically determined for surface sediments, with values of 0.043 and 2.4 for the background and fitting terms, respectively. c) Comparison of measured \%BSi with \%BSi estimated from Si:Ti using fitting parameters determined separately for three segments of the core ( 0 to $2.5 \mathrm{ka}, 2.5$ to 8.0 $\mathrm{ka}$ and 8.0 to $23 \mathrm{ka}$ ). The uppermost section used the parameters described in Fig. 3b, while the parameters for the deeper sections were determined by least squares optimization. This yielded values of 0.050 and 2.1, and 0.053 and 1.6 for the background and calibration terms, for the mid-Holocene and Late Glacial sections, respectively.

borious sequential dissolution (DeMaster, 1979). Even with timesaving modifications (e.g., Johnson et al., 2002), a fulltime technician can process only $\sim 40$ samples in a week. The Si:Ti ratio as determined by XRF ( $\left.\mathrm{Si}: \mathrm{Ti}_{\mathrm{XRF}}\right)$ provides an efficient means of obtaining uncalibrated estimates of $\mathrm{BSi}$, as shown in Lake Malawi sediments (Brown et al., 2007; Fig. 3a).

Calibration of $\mathrm{Si}: \mathrm{Ti}_{\mathrm{XRF}}$ has recently become possible through fitting paired \%BSi with $\mathrm{Si}: \mathrm{Ti}_{\text {XRF }}$ data through application of empirically determined relationships accounting for $\mathrm{Si}$ in clastic minerals and for dilution of clastics by high levels of biogenic material (Fig. 3b).
Comparison of a 25 ka record of measured $\% \mathrm{BSi}$ with \%BSi calculated from Si:Ti ${ }_{\text {XRF }}$ (Fig. 3b) shows that fitting parameters determined from surface sediments may not be appropriate for the entire record, and that least squares fitting of the data in three separate core segments provides a better match (Fig. 3c). The changes in fitting parameters are consistent with generally greater exposure to chemical weathering of more recent sediments that have accumulated under relatively warm and humid Holocene conditions. These results demonstrate the great potential of this approach for providing quantitative results when appropriately calibrated.

\section{References}

Brown, E.T., Johnson, T.C., Scholz, C.A., Cohen, A.S. and King, J.W., 2007 Abrupt Change in Tropical African Climate Linked to the Bipolar Seesaw Over the Past 55,000 Years, Geophysical Research Letters, 34: doi:10.1029/2007GL031240.

Croudace, I.W., Rindby, A. and Rothwell, R.G., 2006: ITRAX: description and evaluation of a new X-ray core scanner. In: Rothwell, R.G., (Ed.) New ways of looking at sediment cores and core data, Geological Society Special Publication, 267: 51-63.

Guyard, H., Chapron, E., St-Onge, G., Anselmetti, F., Arnaud, F., Magand, 0., Francus, P. and Mélières, M.-A., 2007: High-altitude varve records of abrupt environmental changes and mining activity since the Bronze Age in the Western French Alps (Lake Bramant, Grandes Rousses Massif), Quaternary Science Reviews, 26 2644-2660.

Nakagawa, T., 2007: Double-L channel: an amazingly non-destructive method of continuous sub-sampling from sediment cores, Quaternary International, 167-168: Supplement: 298.

Weltje, G.J. and Tjallingii, R., 2008. Calibration of XRF core scanners for quantitative geochemical logging of sediment cores: Theory and application, Earth and Planetary Science Letters, 274: 423-438.

For full references please consult:

www.pages-igbp.org/products/newsletters/ref2009_3.html 


\section{Full Reference List:}

Brown, E.T., Johnson, T.C., Scholz, C.A., Cohen, A.S. and King, J.W., 2007: Abrupt Change in Tropical African Climate Linked to the Bipolar Seesaw Over the Past 55,000 Years, Geophysical Research Letters, 34: doi:10.1029/2007GL031240.

Colman, S.M., Peck, J.A., Karabanov, E.B., Carter, S.J., Bradbury, J.P., King, J.W. and Williams, D. F., 1995: Continental climate response to orbital forcing from biogenic silica records in Lake Baikal, Nature, 378: 769-771.

Croudace, I.W., Rindby, A. and Rothwell, R.G., 2006: ITRAX: description and evaluation of a new X-ray core scanner. In: Rothwell, R.G., (Ed.) New ways of looking at sediment cores and core data, Geological Society Special Publication, 267: 51-63.

DeMaster, D.J., 1979: The Marine Budgets of Silica and ${ }^{32}$ Si, PhD thesis, Yale University.

Guyard, H., Chapron, E., St-Onge, G., Anselmetti, F., Arnaud, F., Magand, O., Francus, P. and Mélières, M.-A., 2007: High-altitude varve records of abrupt environmental changes and mining activity since the Bronze Age in the Western French Alps (Lake Bramant, Grandes Rousses Massif), Quaternary Science Reviews, 26: 2644-2660.

Jansen, J.H.F., Van der Gaast, S.J., Koster, B. and Vaars, A.J., 1998: CORTEX, a shipboard XRF-scanner for element analyses in split sediment cores, Marine Geology, 151: 143-153.

Johnson, T.C., Brown, E.T., McManus, J., Barry, S., Barker, P. and Gasse, F., 2002: A high-resolution paleoclimate record spanning the past 25,000 years in Southern East Africa, Science, 296: 113132.

Nakagawa, T., 2007: Double-L channel: an amazingly non-destructive method of continuous subsampling from sediment cores, Quaternary International, 167-168: Supplement: 298.

Rasmussen, S.O. et al., 2006: A new Greenland ice core chronology for the last glacial termination, Journal of Geophysical Research, 111: D06102, doi:10.1029/2005JD006079.

Rosman, K.J.R., Chisholm, W., Hong, S., Candelone, J.P. and Boutron, C.F., 1997: Lead from Carthaginian and Roman Spanish mines isotopically identified in Greenland ice dated from 600 BC to 300 AD, Environmental Science \& Technology, 31: 3413-3416.

St-Onge, G., Mulder, T., Francus, P. and Long, B., 2007: Continuous physical properties of cored marine sediments. In Hillaire-Marcel, C. and de Vernal, A., (Eds), Proxies in late Cenozoic Paleoceanography, Elsevier, 63-98.

Weltje, G.J. and Tjallingii, R., 2008. Calibration of XRF core scanners for quantitative geochemical logging of sediment cores: Theory and application, Earth and Planetary Science Letters, 274: 423438. 